Review article

Received: 3. July 2019;

Received in revised form: 10. July 2019;

Accepted: 20. July 2019;

Available online: 20. July 2019
UDC 314.7(497.11 Negotin),"19" doi: $10.5937 /$ zrgfub1902069A

\title{
MIGRATION AND POPULATION ORIGIN OF NEGOTIN MUNICIPALITY AT THE BEGINNING OF THE $20^{\mathrm{TH}}$ CENTURY
}

\section{Zlatko Apanović $^{1}$}

\begin{abstract}
The area of the municipality of Negotin, which belonged to the historically important area of Krajina, represented the polygon of intersection of migration flows of different intensity and directions. Studying the origins of the population enables us to understand the currently ethnic division of settlements created by the migrations and ethnic processes that influence the settlements which are the subject of this paper. This article aims to describe the migration flows that determined the origin of the population of the municipality of Negotin and the ethnic distribution of settlements. The results of anthropogeographic surveys conducted during the second and third decades of the $20^{\text {th }}$ century, as well as ethnological research from the second half of the $20^{\text {th }}$ century, can rightly be interpreted as supporting the claim that the origin of the population and the ethnic structure of settlements of the municipality of Negotin are largely the result of historical migration trends. Of the greatest importance for the ethnic distribution of population are its two migration flows. The first and the oldest migration flow from Kosovo and Metohija and stage areas for that migrant lineages (families who have a mutual ancestor) and the second and the most numerous migration flow is from Wallachia, in which the participating lineages of Serbian and Vlach origin which created conditions for further deepening of the differences between Serbian and Vlach settlements.
\end{abstract}

Keywords: Krajina, Negotin municipality, population origin, migration flows, ethnic structure.

\footnotetext{
1 Corresponding author: Z. Apanović; e-mail: apanovic.zlatko@gmail.com
} 


\section{Introduction}

Migration trends have been one of the main features of the Balkan Peninsula for centuries. With their geographical location, this part of Europe has been and remains a bridge between East and West and an important area of integration and intertwining of peoples, cultures and civilizations. The territory of Eastern Serbia, as well as the municipality of Negotin, shared the fate of the Balkans and the direction of migration in this region was shaped under the influence of socio-historical factors.

Based on the results of Kosta Jovanović's research in the period 1912-1925, which thoroughly explored the migration flows of the population that lived in the current municipality of Negotin, it is possible to draw a link between the origin and migration of the population of the past with the present ethnic structure of the population of this municipality. In order to explain the connection between migration and the origin of the population with the ethnic composition of the population, this paper analyzes migration flows that lasted until the end of the $19^{\text {th }}$ century. Settlement surveys conducted by the Village Study Guide, created by Jovan Cvijić, were one of the items for a more complete settlement study aimed at studying the origin of the population, collecting data on all families such as their surname, patron saint (family slava), the number of family members and the place where they migrated from and the causes of migration (Cvijić, 1902). Using the defterler (the Ottoman tax census) of the sanjak of Vidin from the $16^{\text {th }}$ century analyzed by D. Bojanić-Lukač (1969) and the defter of the kadiluk (administrative unit) of Krajina from the $18^{\text {th }}$ century, analyzed by $\mathrm{R}$. Tričković (1973) points to the potential population in the settlements within the confines of today municipality of Negotin. Historical sources, on the other hand, support the claim of an unstable situation, which contributed to the frequent change in the intensity and directions of population movements in this area. Using the census material from the $19^{\text {th }}$ century, it indicates the trends of changing the number of inhabitants created as a result of migrations more than natural increase.

\section{Population migration as a determinant of the demographic development of the municipality of Negotin}

The municipality of Negotin is located in the northeastern part of Serbia, on the border of Serbia, Romania and Bulgaria. The municipality of Negotin has 39 settlements, 38 rural (other) and one urban settlement Negotin which is the municipal, administrative, commercial, economic and cultural center of the municipality. Geographic location, as well as historical events, have largely 
determined migration flows and population composition in the ethnic sense. Openness to the east and the south influenced, on the one hand, emigration in times of crisis, while on the other, this openness enabled both return and new migration flows intensified after the liberation of Krajina. The links, relationships and impact of population changes within demographic systems and their elements with other systems of natural and social species show that migrations influenced with changes in demographic development and transformed population trends and directions of economic, ethnic and social structures.

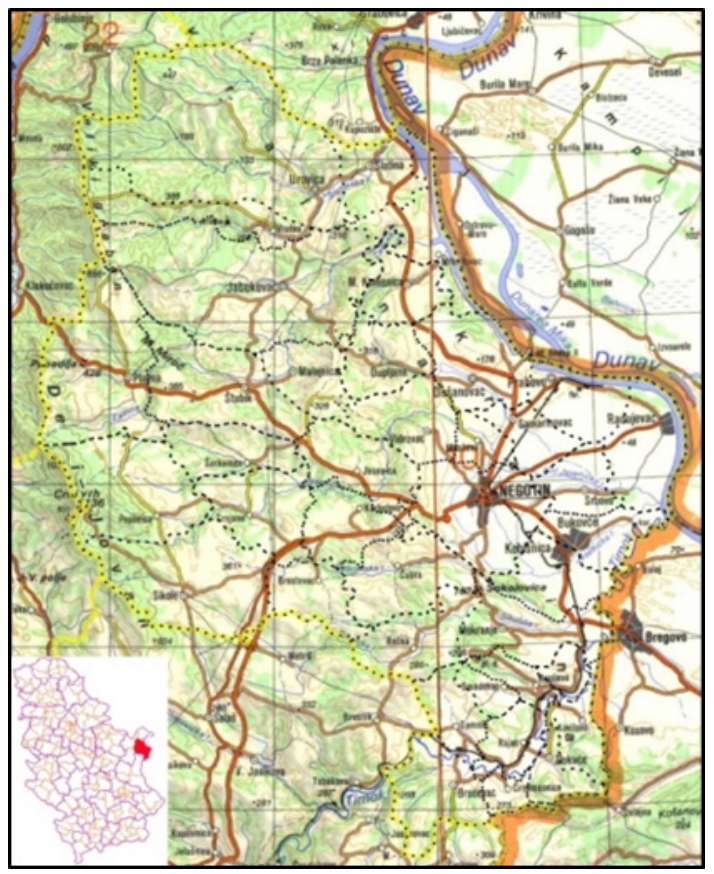

Figure 1. Map of the municipality of Negotin. ${ }^{2}$

\section{The period from the earliest times to the beginning of the $19^{\text {th }}$ century}

Over a long period in history, the main factors of population movements have been political factors, which have led to intense demographic change in this area. The Illyrians and Tribals, suppressed by the Scordisians, are considered to be the oldest inhabitants of this area. It came under Roman rule of the

2 The part of the map of the Military Geographical Institute in the scale of 1: 300000 which reflects the situation from the period 1976-1987 (the map does not mark the settlement Veljkovo between of the settlements Rogljevo and Mokranje). 
year 29 b.c. in the time of the Migration Period, when Krajina became part of Upper Moesia. With the decline of the Roman Empire in the middle of the century, the Goths crossed the Danube and the Huns invaded Europe. At the beginning of the $6^{\text {th }}$ century, these regions were inhabited by Slavic tribes, Negoci and Timaci. Under the onslaught of the Slavs, part of the romanized population fled to the mountainous regions, and this population is considered to be the ethnic basis of the Vlach population in these regions (Stanojević, 1972).

With the development of the first Balkan states, the areas to which the municipality of Negotin belongs today, they belonged to the Bulgarian states and then to the Byzantine Empire for more than a century. With the restoration of the Bulgarian Empire in the $13^{\text {th }}$ century, there was a separation of the Vidin area, which existed as a fully autonomous area within the empire, more precisely as a separate empire (Božilov, 2008). For the first time, this area belonged to Serbia, or Dragutin's kingdom in 1291 (Maksimović, 1981). At the end of the $14^{\text {th }}$ century, in 1396, the Vidin Empire fell under Ottoman Empire, ever since this area formed the classic frontier zone of the Ottoman Empire, open to new conquests (Bojanić-Lukač, 1978).

By administrative division within the Ottoman Empire at the end of $15^{\text {th }}$ and the beginning of $16^{\text {th }}$ century, the Vidin Empire was transformed into the sanjak (province) of Vidin, in which there were 27 settlements that still exist in the Negotin municipality today like Rajac, Tamnič, Smedovac, Rogljevo, Bljuvanovac (Veljkovo), Mokranje and Rečka which belonged to subdistrict (nahiye) of Krivina and the settlements Bukovče, Kobišnica, Čubra, Brestovac, Sikole, Popovica, Jasenica, Šarkamen, Štubik, Trnjane, Vidrovac, Dušanovac, Negotin, Srbovo, Radujevac, Samarinovac, Prahovo, Jabukovac, Vratna, and Slatina which belonged to subdistrict (nahiye) of Fethislam. In addition to the census of 1483, the ferman (imperial order) decreed that inhabited Vlachs (Vlachs as a social, not an ethnic category) were exempt from all rayah (reaya) obligations. In addition, it was ordered that: "infidels who are no one's rayah should be brought from abroad to guard the Ottoman border" (Bojanić-Lukač, 1969: 71). In fact, it was a matter of colonizing the newly conquered lands with residents who would live as free peasants and cattle-breeders and be exempted from the local tax while performing military service in return. Most of the sanjak of Vidin colonized from the sanjaks of Smederevo and Kruševec, and thus the sparsely populated areas of the sanjak of Vidin came to life at the end of $15^{\text {th }}$ and the beginning of the $16^{\text {th }}$ century and strengthened the Serbian ethnic element in this region. After colonization of the Vlach soldiers, began the colonization of the Filurigian Vlachs ${ }^{3}$ who founded or rebuilt abandoned villages (mezre).

3 The Filurigian Vlachs were self-settled and burdened with payment of a filurian taxes that was lower than the rayah payments. The Filhurian system was maintained until 1560 when it was permanently abolished. 
The first census of the subdistricts of Krivina and Fethislam was made in 1530/31-1535, when the subdistrict of Krivina numbered 148 villages with 3498 households, while the subdistrict of Fethislam numbered 101 settlements with 2140 households (Bojanić-Lukač, 1969). If we take into account only those settlements located in the territory of the municipality of Negotin, there were 42 settlements in the subdistrict of Fethislam and 34 settlements in the subdistrict of Krivina. The number of households in the subdistrict of Fethislam could have been between 731 and 1115, and the number of households in the subdistrict of Krivina could have been between 735 and 1024. Based on this, we get that the potential number of inhabitants of the Fethislam part was between 3655 and 8920, while the Krivina part could have been between 3675 and 8192, which gives a total population of 7330 to 17112 (Rašević, 2001; Bojanić-Lukač, 1969). If the censused settlements were classified according to the location to which they would belong today, the number of settlements would be reduced to 32 current settlements.

The expansion of the Ottoman Empire to the north and the abolition of military orders in 1530 resulted in the massive abandonment of estates and entire villages. In response to emigration, Filurigian taxes were established in 1542 for all Vlachs of imperial has (has - the Sultans land) (Bojanić-Lukač, 1975). According to the census of 1586, the settlements of the subdistrict of Fethislam belonging to the municipality of Negotin numbered 722 male-headed households, 59 unmarried man households, and 7 widowed households, while in the subdistrict of Krivina there were 188 male-headed households, 102 unmarried man households, and 1 widow's household. Following the same analogy of the calculation as for the previous period, we get that in the Fethislam part of the Negotin municipality had 3679 inhabitants and in the Krivina part had 1046 inhabitants, which gives a total number of 4743 inhabitants. Accordingly, the population of the settlement of the municipality of Negotin could range from 4743 to 7497 persons (Bojanić-Lukač, 1969). The reasons for the decline of the population number were: the abolition of Vlach military services, the epidemic of plague as well as famine in the unborn years and the "evil of the perpetrators", which represented double taxation of rayah (Jovanović, 1940; Bojanić-Lukač, 1975).

After this wave of emigration, the sanjak of Vidin received a strong immigration wave across the Danube when, during the long Austro-Turkish War (1593-1606), a famine prevailed in Wallachia that led the peasantry to emigrate to the sanjak of Vidin, which, in addition to the significant influx of the population, carried with it and changes in the ethnic composition of this area. The authorities did not prevent the immigrants from returning to Wallachia, but at the same time did not order them to be returned (Bojanić-Lukač, 1969). Jovan Cvijić refers to the fact that the Eastern Serbian regions were almost abandoned in the century due to Turkish rule, and that they were settled at the end of the 
$17^{\text {th }}$ and the beginning of the $18^{\text {th }}$ century, primarily by immigrants from Kosovo (Cvijić, 1991).

The replacement of Austrian and Turkish rule began with the Great AustroTurkish War (1683-1699) when these regions were under Austrian rule for a short time. The withdrawal of the Austrian troops led in 1690 to the Great Migration of Serbs, where the population of Old Serbia and Macedonia went north, one branch east, and the population of northeastern Serbia went toward Wallachia and Moldova. For this period, the first immigrants in the area of the current municipality of Negotin were the Serbian population which belongs to the migration flow from Kosovo and Metohija. At the beginning of the $18^{\text {th }}$ century, these areas were almost abandoned due to frequent wars and passage of various armies, so the Austrian census of 1718 showed that there were only 17 inhabited and 4 uninhabited places in the district of Krajina, with 130 censused inhabitants, while in the district of Krivina were 9 inhabited and 5 uninhabited places with 38 censused inhabitants (only settlements within the borders of today's Negotin municipality were taken into account). D. Pantelić (1948) states this is not about individuals but households and zadrugas (extended families).

Austria pursued its colonization policy in this region with two goals: the first goal was economic development that would contribute to higher tax revenue and the second was the military-strategic goal related to the defense of the border. The increase in taxes in 1719, the introduction of unpaid hard work like slavery (kuluk), as well as the appearance of various forms of violence, caused dissatisfaction with the rural population, especially in the districts of Krajina, Golubac and Kuč. The northern areas of the Ottoman Empire had lower taxes to attract the population who lived on their land until the loss of their territory, and in 1720 Porta declared that anyone who moved to Niš area from "Germany" would be exempt from all taxes in the next three years. The data show that in the Niš area in 1721, after the forgiveness of the post-war debt, there were about 10000 tax sheets, while by 1726 that number had reached 15000 (Samardžić, 1986). It can be assumed that, of the total number of those who moved to Turkey, there were certainly some persons from the settlements of the Negotin municipality area. On the other hand, the increase in contributions in 1734 indicates that these regions were experiencing emigration waves to Banat, Wallachia, and Turkey (Pecinjački, 1974). After the Austro-Russian-Turkish War (1737-1739), Austria made a proclamation to the population of the district of Negotin, which aimed to attract and relocate the population of these areas to Banat, primarily of entire settlements and subsequently individual migration (Pecinjački, 1974).

With the reestablishment of its authority, the Turkish administration conducted a census of 1740-1741, which offered much more information, because, in addition to the name, there was a father's name, nickname, occupation or place from which the person immigrated and the number of refugees. The 28 
settlements of the kadiluk of Krajina, which are now part of the Negotin municipality with 1474 tax heads, while the total population would range between 7370 and 11792 people. Migration characteristics, which are also ethnic characteristics, are also evidenced by names: Grkul, Grek or Grekul, Bulgaria, Bulgarin or Bulgar, Turk, German, Tatar, Vlach, Unguran, Caran, Srbul, Kraguj, Jagodin, Košovan, Samarinova, Trnjan, Glogovičan, Jablaničan, Dobra, Poreč, Bela Reka, Fethislam, Vidin, Oltan, Ostrovan, Halmašan, Basarba, Papuš. In this way, we learn directly that in the settlements of the Negotin municipality, the number of Vlachs or those who immigrated from Wallachia was 66 tax heads, 8 from Greece, 10 from Bulgaria, 7 from Serbia and 3 from Kosovo, 5 from Kragujevac, Jablanica and Jagodina, 9 from villages of the kadiluk of Krajina or in the immediate vicinity and 1 from Turkey. Although these data does not give us a true picture of the ethnic structure, they do indicate a tendency to lead those who immigrated from Wallachia because the aim of the Ottoman Empire was to settle and secure a border zone with Austria.

\section{The influence of migration trends on population dynamics during the $19^{\text {th }}$ century}

The end of the $18^{\text {th }}$ and the beginning of the $19^{\text {th }}$ century in Krajina is known for a difficult time, as evidenced by the great emigration from Krajina to Homolje and Zvižd (Lazić, 1938). The Serbian uprising, launched in 1804, spread the liberation ideas to the northern part of the sanjak of Vidin, and in 1807 an important battle ensued at Štubik and Malajnica which resulted with the liberation of Krajina and Ključ (except Kladovo). In the period from 1807 to 1810, Krajina passed from Serbian to Turkish hands vice versa. "About 15000-20000 people at the end of 1813 meant a shortfall in the real demographic structure of Eastern Serbia, which would say that every sixth, if not every fifth inhabitant of these regions died, fell into slavery or emigrated" (Stojančević, 1983, pp. 134-135). The northern parts of the sanjak of Vidin were in a difficult position during the Russian-Turkish War (1828-1829) because they were close to the battle areas and the obligation to the Turkish army, which caused the emigration of the population to Serbia (Stojančević, 1983). In 1833, the regions of Eastern Serbia were annexed to the Principality of Serbia, and the tax relief policy that Miloš Obrenović sought to settle in the liberated area was a major factor in the migration or return of the refugee population. In particular, because of tax breaks, greater freedoms and the right to acquire free possessions, the immigrants from Wallachia settled to Krajina (Stojančević, 2003). In support of this is the establishment of the village of Mihajlovac in 1834 by a dissatisfied population who, with their movable property, moved from the Veliko Ostrvo (Ostrovul Mare) to the opposite coast 
of the Danube to the Principality of Serbia (Đordjević, 1926; Janković, 1966). In the census of 1834, the number of inhabitants in settlements of the Negotin municipality was 23933 persons (Cvejić, 1984), of which Serb villages numbered 8518 inhabitants, in Vlach villages, there were 13315 persons, while in Negotin there were 2100 inhabitants. By the end of the $19^{\text {th }}$ century, the population in the town of Negotin reached 6267 inhabitants, in the Serbian villages, there were 18529 persons, while the Vlach settlements numbered 28991 inhabitants, which was certainly contributed by the migration movements intensified after the first census.

Table 1. Population trends in Serbian and Vlach settlements and the average annual growth rate in the period 1834-1900.

\begin{tabular}{|c|c|c|c|c|c|c|c|}
\hline \multicolumn{8}{|c|}{ Population } \\
\hline Census year & 1834 & 1854 & 1866 & 1874 & 1884 & 1890 & 1900 \\
\hline Total & 23933 & 33221 & 40557 & 42978 & 46134 & 50891 & 53787 \\
\hline Negotin & 2100 & 3494 & 4325 & 4528 & 4727 & 5386 & 6267 \\
\hline Serbian settlements & 8518 & 12026 & 14660 & 15544 & 16467 & 17991 & 18529 \\
\hline Vlach settlements & 13315 & 17701 & 21572 & 22906 & 24940 & 27514 & 28991 \\
\hline \multicolumn{8}{|c|}{ Average annual population growth rate (\%0) } \\
\hline Inter-census period & & $\begin{array}{l}1854 / \\
1834\end{array}$ & $\begin{array}{l}1866 / \\
1854\end{array}$ & $\begin{array}{l}1874 / \\
1866\end{array}$ & $\begin{array}{l}1884 / \\
1874\end{array}$ & $\begin{array}{l}1890 / \\
1884\end{array}$ & $\begin{array}{l}1900 / \\
1890\end{array}$ \\
\hline Total & & 15.85 & 17.29 & 7.25 & 7.08 & 16.34 & 5.53 \\
\hline Negotin & & 24.31 & 18.48 & 5.73 & 4.30 & 21.72 & 15.12 \\
\hline Serbian settlements & & 16.66 & 17.17 & 7.32 & 5.77 & 14.74 & 2.95 \\
\hline Vlach settlements & & 13.80 & 17.14 & 7.50 & 8.50 & 16.36 & 5.23 \\
\hline
\end{tabular}

Source: Cvejić, L. (1984); Državopisi Srbije sv. 3, 9, 16; Glasnik Društva srpske slovesnosti, sv. 9; Prethodni rezultati popisa u Kraljevini Srbiji 1980. Knjiga 1, I deo; Statistika Kraljevine Srbije, Knjiga XXIII; Popis stanovništva i domaće stoke u Kraljevini Srbiji 1900.; average annual population growth rate calculated by the author.

\section{Migration flows and population origin}

In the period from 1912 to 1925, the total number of immigrant lineages and the number of their homes in the settlements of the municipality of Negotin was 971 lineages with 9027 homes (Jovanović, 1940).

The largest number of immigrant lineages had the strongest migratory flow in these areas, which Kosta Jovanović characterized as Romanian-Serbian migratory flow. The descendants of lineage displaced by this migration flow num- 
bered $320(32.96 \%)$ lineages with 3242 (35.91\%) homes at the beginning of the $20^{\text {th }}$ century. The migration flow was mostly made up of settlers from the borderland plain of Wallachia and is called Carani, and the name itself derives from their agricultural profession (Tara/Cara - land). The second group consists of immigrants from Almaš in Banat and Erdelj or Transylvania. Considering that Banat and Erdelj belonged to the Hungarian, settlers of this migratory flow were called Ungureani - Ungurjani (Cvijić, 1991). In relation to the total number of settlers of this migration flows, Ungureans numbered only 36 lineages with 353 homes. In addition, a large number of settlers of Romanian-Serbian migration flow belong to inverse migrations. Lineages which returned to Krajina's settlements in the Danube coast (from which the largest number of Caran lineages), migrated from Veliko Ostrvo (Ostrovu Mare), Balta Verđi (Balta Verde), Ciganaš (Tiganasi), Gruja (Gruia), Izvorul (Izvoarele), Burila (Burila Mika and Burila Mare), Dančev (Dănceu), in general, the area of Little Wallachia (the area of Oltenia) near the coast of the Danube. Ungureans came from Erdelj, Almaš and are generally characterized as Ungureans, without more precise distribution of the settlements from which they came from or returned to.

This migration flow has a big influence on the ethnic structure of the population of Vlach settlements, while the number of lineages that belonged to this migration flow to Serbian settlements was only 17 lineages with 91 homes. In the local migrations, which were mostly directed towards Vlach settlements, the population of Vlach origin was mostly involved, from settlements belonging to the group of Serbs, but vice versa, most of the lineages who participated in the migration to Serb villages were mostly immigrants from Kosovo and Metohija, Dinaric regions or ethnic Serb population.

The second-largest migration flow is made up of members whose origins are from Kosovo and Metohija which numbered 213 lineages with a share of $21.94 \%$ in the total number of lineages and 2107 (23.34\%) homes. Kosovo-Metohian migration flow was much stronger until the beginning of the $19^{\text {th }}$ century when settlements of the municipality of Negotin were mostly settled from the main areas of this migration flow, respectively from Kosovo and Metohija. However, during the $19^{\text {th }}$ century, the largest number of settled lineages of this migration flow came from stage regions, especially from Crna Reka, Timok, Poreč, Homolje, Sumadija, etc. Stage migration settlements of this population, which are close to the municipality of Negotin are Donja Bela Reka, Kosovo in Bulgaria, Krepoljin, Krivi Vir, Lenovac, Neresnica, Rgotina, and Trnavac. Generally, lineages of this migration flow defined the group of Serb settlements in the ethnic sense. This migration flow was certainly present even years ago by the Great Migration of Serbs, but it was significantly amplified at the time, as one part of lineages continued across the Danube and the Sava, while the other part went to northeastern Serbia. As already mentioned, in local migrations directed towards the 
group of Serb settlements, lineages of this migratory flow were mostly involved. Also, in a certain number of lineages belonging to the Timok-Braničevo migration flow, there have been lineages whose origin is from Kosovo and Metohija, and to whom the settlements of Crna Reka and Timok were the destination of stage migration. This migration flow numbered only 25 lineages with 129 homes in Vlach settlements.
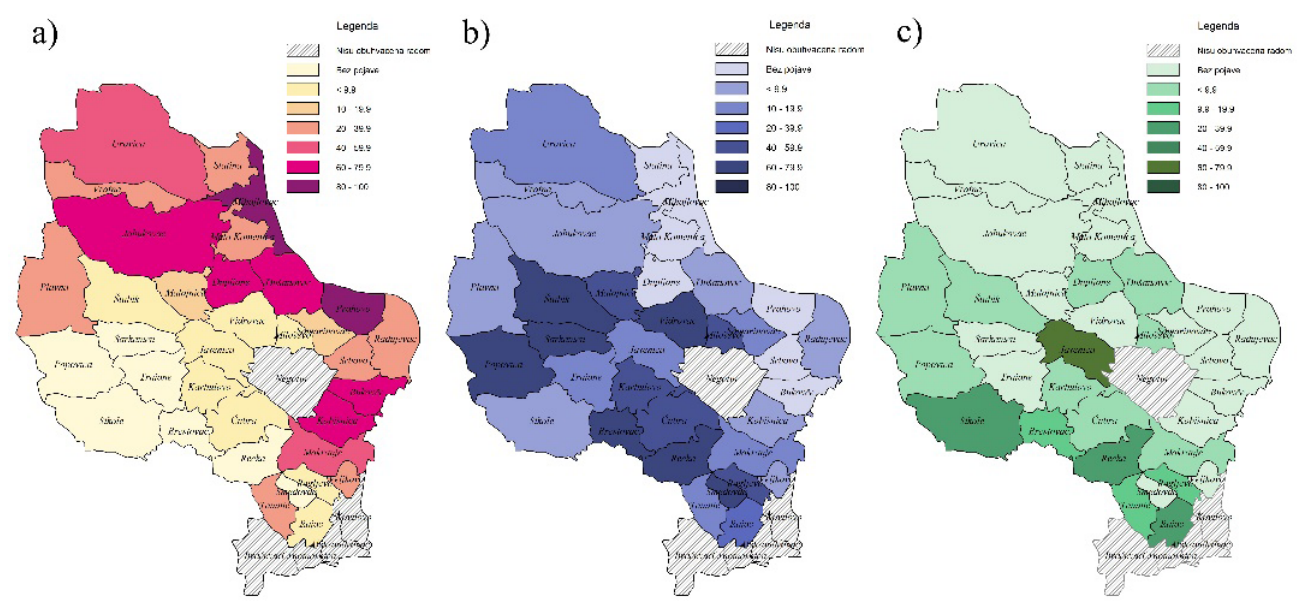

Figure 2. Settlements of Negotin municipality at the beginning of the $20^{\text {th }}$ century by the share of kindred belonging to the relevant migration flows: a) Romanian-Serbian, b) Kosovo-Metohian and c) Dinaric.

The Dinaric migration flow, whose area where are they came is known as "Arnautluk" numbered 54 (5.56\%) lineages with 747 (8.28\%) homes, and their origin was Serbian. The starting points for this migration flow were Sjenica or Ravna Sjenica, Stari Vlah, Užice, Šumadija (Gornji Vilajet), Montenegro and Bosnia and Herzegovina. In most cases, they directed their movements to Serbian settlements and founded one of them, whose name is Jasenica.

The Timok-Braničevo migration flow, which in the starting area belongs settlements of the municipality of Negotin, numbered $87(8.96 \%)$ lineages and $834(9.24 \%)$ homes. Migration from these regions was intensified after the liberation of Krajina. It mostly involved the population of the surrounding settlements from areas Crna Reka, Timok, Homolje, Poreč and Zvižd, while to a lesser number lineages migrated from Braničevo and Požarevac area. In addition to settlements that belong to the current borders of Serbia, this migration flow also consisted of settlers whose was starting areas from the border area of northwestern Bulgaria, such as settlements Balej, Bregovo, Rakovica, Vrf, etc. 
Lineages of Shopp migratory flow significantly fewer inhabitants, respectively 65 lineages $(6.69 \%)$ with $431(4.77 \%)$ homes. The settlers of this migration flow were mostly settled after the liberation of these regions since the original areas in which these settlements lived were util 1878 under Turkey. The largest number of migrants from this migratory flow come from parts of today's Bulgaria, while a much smaller number (with one person participating), comes from parts of southeastern Serbia. Of the settlements in Serbia, Pirot or its surroundings, Vlasotince, Zaječar and Veliki Izvor are mentioned in most cases. The settlements in Bulgaria that gave significantly more migrants to this migration flow were Vidin, Deljen, Kula, Lom Palanka, Novo Selo, Svištovo, Trnovo, Čunguras and Šišinci.

Vardaro-Moravian migration flow is the least represented in the settlements of the municipality of Negotin. This migration flow had only 8 lineages by the end of the $18^{\text {th }}$ century. During the $19^{\text {th }}$ century it comes to another 16 lineages, and the number of descendant lineages who participated in this migration flow was $24(2.47 \%)$ with $192(2.13 \%)$ homes. In the first wave of migration, immigrants from Macedonia (Bitolj, Veles, Gostivar, Gopeš, Kičevo, Ohrid, Prilep, Tetovo), from south regions under the Ottomans and from Greece, mostly migrated to Serbian settlements, while in the period from the beginning of the $19^{\text {th }}$ century, they also settled to Vlach settlements.
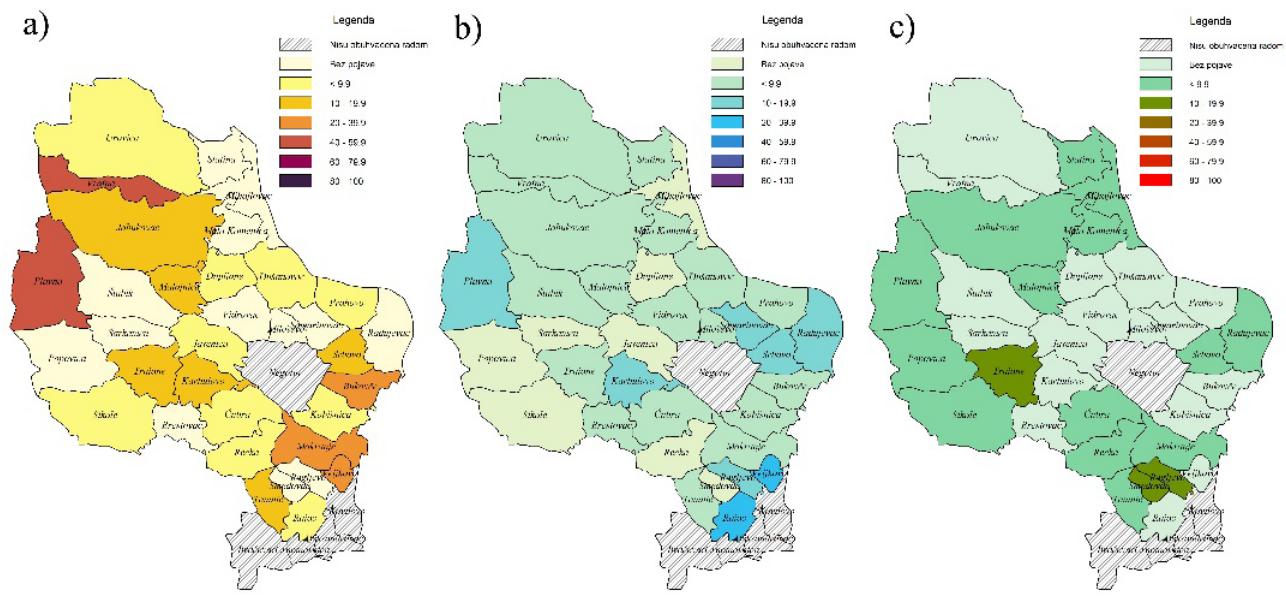

Figure 3. Settlements of Negotin municipality at the beginning of the $20^{\text {th }}$ century by the share of kindred belonging to the relevant migration flows: a) Timok-Braničevo, b) Shopp and c) Vardaro-Moravian.

Lineages who participated in the inverse migrations, respectively of the returnees, mostly came from Wallachia, Transylvania, and Bulgaria, then from Šumadia, Smederevo and Požarevac, and to a lesser extent from Austria, Turkey 
and Russia. Immigrants who, due to wars, fiscal burdens and raids, fled to the mentioned areas and then returned (in most cases after the liberation of Krajina) belong to this migration flow. Certainly, the inverse migration flow intensified after the liberation and was mostly directed towards Vlach settlements.

Local migrations were attended by lineages of both Serbian and Vlach descent, mostly towards settlements dominated by the population of their ethnic milieu. This type of migration was considerably intensified in the $19^{\text {th }}$ century, and this is compounded by the fact that it was freer to move within the territory of the liberated country to which these settlements belonged after the accession of the Principality to Serbia. The number of lineages who participating in this type of movement was $74(7.62 \%)$ with $207(2.29 \%)$ homes. However, their number would be significantly higher if all local movements were included in these migrations, no matter which origin migration flow they belong.

The settlers of unknown origin mostly inhabited the Vlach settlements, and in some of them, they were the founders, for example, Mala Kamenica or Miloševo which they founded together with the settlers of the Kosovo and Metohija. At the time of the survey, their share was $9.06 \%$ of lineages and $9.14 \%$ of homes. In most cases, as stated by Kosta Jovanović, these are lineages immigrated from Wallachia, and the question remains whether they are of Serbian, Vlachs or another origin.

Descendants of the oldest lineages who lived in this area before all mentioned migration flows were recorded in only two settlements, Sikole and Trnjane and counted a total of 28 (2.88\%) lineages with 294 (3.26\%) homes.

From all of the above, it can be determined how much the migration flows and the origin of the population that participated in the establishment or reconstruction of the settlement had an impact. Local migrations influenced the attraction of the population to settlements with the same ethnic characteristics, which served as a factor in deepening the differences between Serbian and Vlach settlements (Zivkovic i Sabic, 2002; 2003). In addition, the model of the economy, as well as the hypsometric distribution of settlements, was one of the most significant factors of attraction for certain immigrant flows, which determined the greater diversity of the population according to ethnic characteristics in the same settlement, like Serbian from Kosovo and Metohia and Vlachs Ungureans. Inverse migration increased the wave of settlers towards Vlach settlements, since the population that participated in this migration flow came mostly from Wallachia and the settlements, and despite the fact that a number of these settlers were of Serbian origin, they returned to their ancestral settlements had the characteristics of the area from which these migratory flows began. Thus, there were $87(8.96 \%)$ with $486(5.38 \%)$ homes in the survey period at the beginning of the $20^{\text {th }}$ century. 


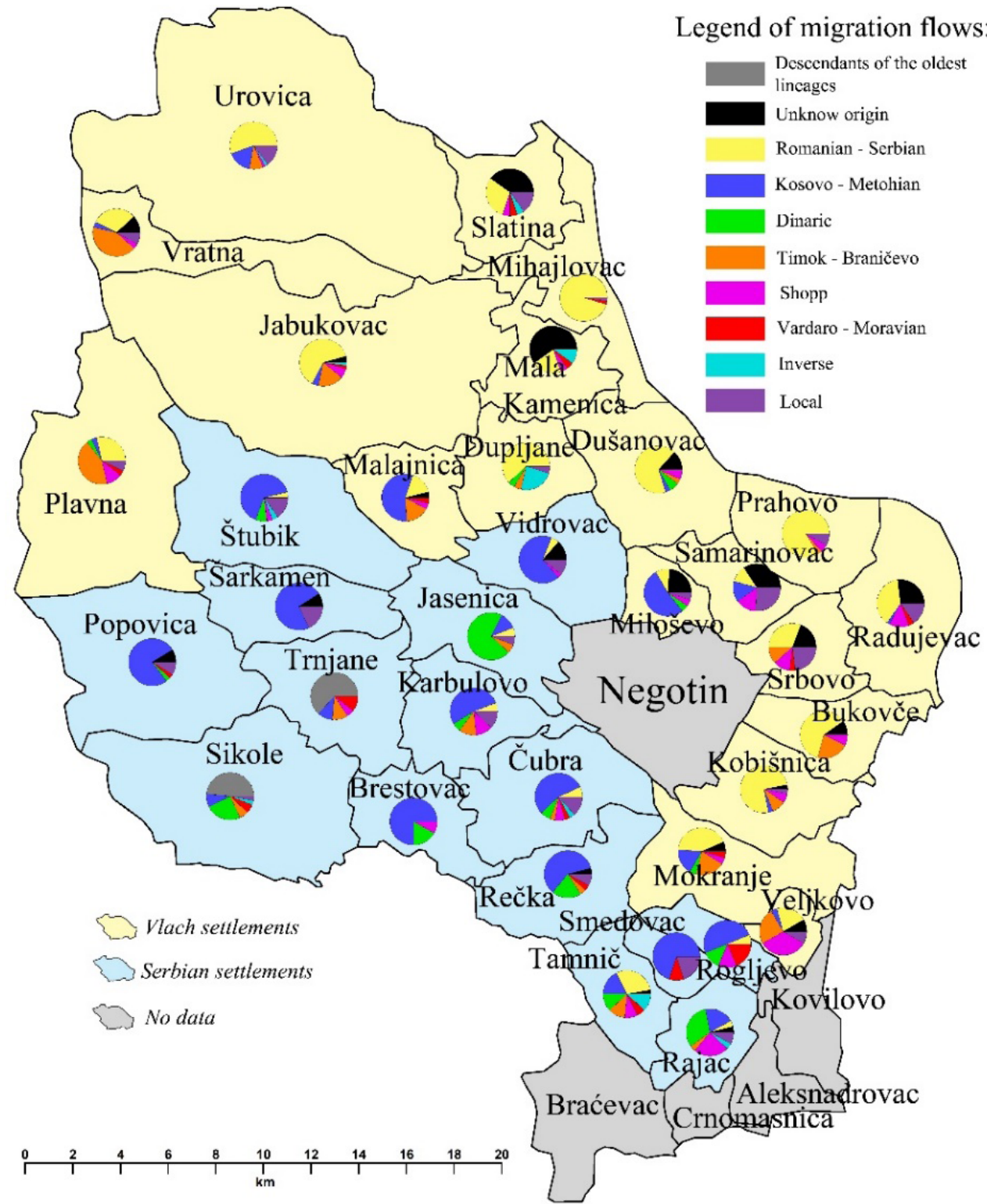

Figure 4. Settlements of the municipality of Negotin at the beginning of the $20^{\text {th }}$ century by the share of lineage belonging to the migration flows and by the division of settlements into Serbian and Vlach. ${ }^{4}$

4 The division of settlements into Serbian and Vlach's is taken from the paper work of Miroslav Draškic, which is on the literature list. 


\section{Conclusion}

The ethnic composition of the population in the settlements of the municipality of Negotin arose as a result of migration processes in these areas and the differentiation of settlements into Serbs and Vlachs. The migration flows that defined the population of Serbian settlements are Kosovo-Metohian, Dinaric and to a lesser extent Vardaro-Moravian and Shopp, while the formation of Vlach settlements is mostly due to the Romanian-Serbian migration flow and to a large extent inverse to which the majority of Vlach returnees belong. TimokBraničevo migration flow, as well as local movements, played the role of stage destinations from which the lineages then moved to settlements with the largest number of settlers of their origin. Lineage of Romanian-Serbian migration flow (exclusively Carani) inhabited the lowland villages on the right coast of the Danube river, which is closely related to their mode of economy, respectively agriculture. On the other hand, a much smaller number of settlers from the Romanian-Serbian migration flow from the hilly and mountainous regions of Romania and Banat, (Ungureans) settled to places with similar geographical characteristics, and the lineages of these settlers are also located in settlements considered Serbian. Lineages which origin is from Kosovo and Metohija and Dinaric areas settled in the western part of the municipality at higher altitudes and settlements in the Timok basin. The migratory flow from Moravian and Vardar areas are characterized by a small number of migrants and the absence of certain settlements where their concentration is higher. Lineages from Shopp migratory flow was mostly concentrated in villages around Negotin, as well as in larger rural settlements like Jabukovac. The lineages of the Timok-Braničevo migration flow mostly immigrated after the liberation of Krajina, coming from the border areas around Krajina. In addition, Kosovo, Dinar and Vlach settlers who migrated in stages came along. The situation is similar to local migration, which was reflected through the migration of lineages to villages dominated by the population of their origin, which certainly had an effect on the increased difference between Serb and Vlach settlements.

\section{Literature}

Božilov, I. (2008), Bugarska u srednjem veku, U: Grupa autora, Istorija Bugarske, Polis/ Clio, Beograd, 2008, 67-121.

Bojanić-Lukač, D. (1969), Negotinska krajina i Ključ u vreme turske vladavine na osnovu izvora iz XV i XVI veka, Glasnik Etnografskog muzeja, Broj 31-32, Negotinska krajina, Beograd, 1969, 65-109 
Bojanić, D. (1973), Fragmenti zbirnog popisa vidinskog sandžaka iz 1466. godine, Istorijski institut, Građa-Knjiga 11, Mešovita građa-Knjiga 2, Beograd, 1973, 5-11

Bojanić-Lukač, D. (1978), Zaječar i Crna Reka u vreme turske vladavine (XV-XVIII vek), Glasnik Etnografskog muzeja, Knjiga 42, Beograd, 1978, 23-77.

Veselinović, R. (1986), Srbija pod austrijskom vlašću 1718-1739, U: Grupa autora, Istorija srpskog naroda, Cetorta knjiga, Proi tom, Srbi u XVIII veku, Beograd, 1986, 109-111.

Draškić, M. (1969), Poreklo stanovništva i etnički procesi u selima negotinske opštine, Glasnik Etnografskog muzeja, Broj 31-32, Negotinska krajina, Beograd, 1969, 11-63.

Janković, S. (1966), Jedan momenat iz istorije naseljavanja Krajine, Razvitak, Godina VI, Broj 1, Zaječar, 1966, 69-74.

Jovanović, K. (1940), Negotinska krajina i Ključ, Srpski etnografski zbornik, Srpska Kraljevska Akademija, Knj. 55, Prvo odeljenje: Naselja i poreklo stanovništva, knj. 29, Beograd, 1940, 25 i 71-251.

Lazić, A. (1938), Etničke promene u Homolju i Zviždu, Glasnik Geografskog društva, Sveska XXIV, Beograd, 1938, 83-84.

Maksimović, Lj. (1981), Počeci osvajačke politike, U: Grupa autora, Istorija srpskog naroda, Knjiga proa, Od najstarijijh vremena do Maričke bitke (1371), Beograd, 1981, 437-449.

Pantelić, D. (1948), Popis pograničnih nahija Srbije posle Požarevačkog mira, SAN, Spomenik XCVI, Drugi razred, 75, Beograd, 1948, 8-10.

Pecinjački, S. (1974), Proklamacija generala Engelshofena iz 1737. godine stanovnicima Crne Reke i Timočke krajine, Istorijski institut, Građa Knjiga 14, Mešovita građa Knjiga 3, Beograd, 1974, 77-80.

Rašević, M. (2001), Demografske prilike i stanovništvo, U: Grupa autora, Naselja $i$ stanovništvo oblasti Brankovića 1455. godine, SANU, Beograd, 2001, 428.

Samardžić, R. (1986), Srbija od Požarevačkog do Beogradskog mira 1718-1739, U: Grupa autora, Istorija srpskog naroda, Četorta knjiga, Proi tom, Srbi u XVIII veku, Beograd, 1986, 99.

Stanojević, T. (1972), Negotin i Krajina-Od proih tragova do 1858. godine, Zajednica kulture SO Negotin-Novinska ustanova "Timok“, Negotin, 1972, 11.

Stojančević, V. (1983), Iz istorijske prošlosti Istočne Srbije (1804-1833), Istorijski arhiv „Timočka Krajina“, Zaječar, 1983, 9-59.

Stojančević, V. (2003), Etno istorijski procesi u istočnoj Srbiji u 19. veku, Istorijski arhiv Negotin, 2003, 37-90.

Tričković, R. (1973), Popis harača Krajine i Ključa za 1153. godinu po hidžri, Istorijski institut, Građa Knjiga 11, Mešovita građa Knjiga 2, Beograd, 1973, 193-241.

Cvejić, L. (1984), Popis stanovništva i imovine u Srbiji 1834. godine, Istorijski institut Građa knj. 25, Mešovita građa knj. 13, Beograd, 1984, 22-29. 
Cvijić, J. (1902), Antropogeografski problemi Balkanskog Poluostrva, Srpski etnografski zbornik, knj. IV, Prvo odeljenje, Naselja srpskih zemalja, knj. I, Beograd, 1902, IX-XXI

Cvijić, J. (1991), Balkansko poluostrvo, Sabrana dela, Knjiga 2, SANU, Zavod za udžbenike i nastavna sredstva, Književne novine, Niš, Prosveta, 1991, 169-170.

Živković, Lj. i Šabić, D. (2003), Neka demografska obeležja Negotinske krajine, U Đorđević, Lj., Maruški, P. i Milić, N. (ur.): Ekološka istina, XI naučno-stručni skup o prirodnim vrednostima i zaštiti životne sredine, Tehnički fakultet - Bor, Univerzitet u Beogradu, Zavod za zaštitu zdravlja - Zaječar i Društvo mladih istraživača, Donji Milanovac, 478-482.

Živković, Lj. i Šabić, D. (2002), Obrazovna struktura stanouništva Negotinske krajine, U Đorđević, Lj., Maruški, P. i Milić, N. (ur.): Ekološka istina, X naučno-stručni skup o prirodnim vrednostima i zaštiti životne sredine, Tehnički fakultet - Bor, Univerzitet u Beogradu, Zavod za zaštitu zdravlja - Zaječar i Društvo mladih istraživača, Donji Milanovac, 572-574. 